\title{
The Optimality of Using Marginal Land for Bioenergy Crops: Tradeoffs between Food, Fuel, and Environmental Services
}

\author{
Adriana M. Valcu-Lisman, Catherine L. Kling, and \\ Philip W. Gassman
}

\begin{abstract}
We assess empirically how agricultural lands should be used to produce the highest valued outputs, which include food, energy, and environmental goods and services. We explore efficiency tradeoffs associated with allocating land between food and bioenergy and use a set of market prices and nonmarket environmental values to value the outputs produced by those crops. We also examine the degree to which using marginal land for energy crops is an approximately optimal rule. Our empirical results for an agricultural watershed in Iowa show that planting energy crops on marginal land is not likely to yield the highest valued output.
\end{abstract}

Key Words: bioenergy crops, food, fuel, marginal land, multi-objective optimization, water quality

A vigorous debate has emerged over the past decade concerning use of the world's land resources as concern about feeding growing populations, particularly in the developing world, has become prominent in public discourse (Ray et al. 2013, Godfray et al. 2010). In addition, ethanol production has increased dramatically in many countries during the same period, creating added demand for agricultural land (Harvey and Pilgrim 2011). This increased use of ethanol has come about in part due to public

Adriana M. Valcu-Lisman is a post-doctoral research associate Catherine L. Kling is director of the Center for Agricultural and Rural Development and Charles F. Curtiss Distinguished Professor in the Department of Economics Philip W. Gassman is an associate scientist, all with the Center for Agricultural and Rural Development in the Department of Economics at Iowa State University. Correspondence: Adriana Valcu-Lisman " Center for Agricultural and Rural Development " 581 Heady Hall " 518 Farm House Lane " Ames, IA 50011-1054 " Phone 515.294.8014 - Email amvalcu@iastate.edu.

This research was funded in part from support received from the U.S. Department of Agriculture's National Institute of Food and Agriculture (grants 2014-51130-22494, 2011-68005-30411, and 2011-68002-30190); the National Science Foundation's Water, Sustainability, and Climate program jointly with the National Institute of Food and Agriculture (grant NSF-WSC1209415); and the Iowa Water Center - DOI U.S. Geological Survey 424-40-17.

We thank Todd Campbell for technical assistance and helpful suggestions. The views expressed are the authors' and do not necessarily represent the policies or views of any sponsoring agencies. All errors remain our sole responsibility.

Agricultural and Resource Economics Review 45/2 (August 2016) 217-245

(C) The Author(s) 2016. This is an Open Access article, distributed under the terms of the Creative

Commons Attribution licence (http://creativecommons.org/licenses/by/4.0/), which permits unrestricted re-use, distribution, and reproduction in any medium, provided the original work is 
policies that subsidized the growth of the industry. These policies were motivated by several objectives, one of which was to spur development of second-generation feedstocks (such as ones produced from perennial grasses), which are expected to generate substantial benefits in terms of reduction of greenhouse gas (GHG) emissions. The second-generation feedstocks may also generate water quality benefits and provide habitat for plants and animals in highly agricultural regions of the United States.

During the mid to late 2000s, grain prices spiked in much of the developing world, contributing to food instability and hunger (Guariso, Squicciarini, and Swinnen 2014, Wright 2011), and policies that promoted ethanol production in the developed world were identified as a possible culprit for those spikes (Tokgoz et al. 2008, Hausman 2012, Tadasse et al. 2014). However, crop failures due to drought, combined with trade restrictions imposed by economically stressed countries, have been identified as primary sources as well (Anderson and Nelgen 2012). Despite recognition that the cause of the price spikes was multifaceted, the concern about competition between food and fuel production on agricultural lands has become something of a black eye for any form of ethanol production with some arguing that biofuel crops, which inherently compete for land with traditional food and fiber crops, should not be subsidized or grown at all.

As previously noted, one of the original goals of biofuel policies was to support a path to less-carbon-intensive fuels. While ethanol from corn grain appears to have, at best, moderate GHG-reducing characteristics (Morales et al. 2015), the original biofuel mandates in the United States and affiliated legislation were also designed to speed the process of developing and implementing second-generation biofuels produced from perennial crops such as switchgrass and miscanthus. The technology for converting those crops to fuel is not yet mature; if it does develop to the point of commercialization, significant GHG reductions are possible (Limayem and Ricke 2012). Furthermore, an attractive co-benefit of planting perennials across the landscape is that these plants simultaneously retain nutrients (nitrogen and phosphorus) and reduce soil erosion and thus would likely achieve significant improvements in water quality in many degraded lakes and streams and increase the level of carbon sequestered in the soil.

Given the potential environmental benefits associated with ethanol, particularly second-generation biofuels, some have argued that biofuels should be developed, but their production should be restricted to planting on "marginal" land to avoid competing with food crops (Gelfand 2013, Shortall 2013). Interestingly, there is no agreed-on definition of marginal land, and, in general, the term has been used to define two broad types of land. ${ }^{1}$ In one

\footnotetext{
1 Debates discussing and defining the term "marginal" land have a long history. An early contribution defining this concept is Peterson and Galbraith (1932) in an article entitled "The Concept of Marginal Land."
} 
case, marginal land has been used to refer to land that has low productivity in terms of yield. In other cases, marginal land is land that is considered environmentally sensitive-locations with high erosion rates or proximity to streams and rivers are typical examples. While there may be cases of overlap between these two definitions, there is no guarantee that will be the case. Indeed, a number of studies have been completed to identify sources of marginal land based on competing definitions (Lewis and Kelly 2014, Shortall 2013).

The purpose of restricting biofuel crops to marginal land is to minimize competition between food prices and ethanol/energy prices, thereby protecting the food supply and preventing price spikes such as those seen in the mid to late 2000s, and to harness the benefits of biofuels to mitigate global climate change and improve water quality (as well as other ecosystem benefits affiliated with perennial crops). There are several shortcomings in this logic in terms of maximizing social welfare. The first problematic aspect is the focus on maintaining stable grain prices. Price variability is key to sending correct market signals to both producers and consumers. Prices that correctly reflect supply shortages due to drought or other conditions can encourage reduction of food waste, alteration of diets to reflect adequately supplied commodities, and other valuable adjustments.

A second issue is that land, like all inputs, will best serve human purposes when it is used to produce goods and services that are most valued. While food is obviously a critically important good, the supply of food varies widely across space and increased production often has little to do with successfully distributing food to the neediest. Furthermore, food is not a single commodity. Indeed, corn grain, which is used to produce ethanol in the United States, is arguably not "food" at all, as its use within the food sector is primarily for animal feed and it is an inefficient way to produce calories and nutrition. The argument that we should avoid competition between food and fuel crops implies that energy is always lower valued than corn grain for animal feed. The lack of a market price for any of the externalities associated with agricultural production, including water quality, suggests that present allocations of land likely are not ideal.

An alternative approach is to ask how agricultural lands should be used to produce the highest valued outputs in terms of food, energy, and water quality. In this standard economic framework, it is possible that allocating land to food and energy crops could be at, or approximately at, its highest value when bioenergy crops are located on marginal land and food crops are placed on nonmarginal land. This could be due to the relative value of food versus fuel or to the nonmarket value of water quality (or a combination of the two).

In this study, we explore the efficiency tradeoffs associated with allocating land between food and energy crops and the degree to which using marginal land for bioenergy crops is an approximately optimal rule. To do so, we focus on a watershed in Iowa using a highly detailed model of land use that is 
generally representative of much of the agricultural land in the region. We consider food crops (grain production from corn and soybeans) grown under three management practices (traditional cropping, use of cover crops, and reduced tillage) that each impose a different cost. In addition to grain production, corn can be used to produce ethanol. We also consider two additional sources of biofuel production: removal of stover and its conversion to ethanol and planting of switchgrass or miscanthus (perennial biofuel feedstocks currently being developed as productive "second generation" biofuels).

Improved water quality measured by reduced nitrogen and soil erosion concentrations in waterways can be generated in several ways from changes in cropping patterns and management practices. Taking production of a corn/soybean rotation as the base of comparison, adding a cover crop and/or reducing tillage has positive water quality benefits in terms of both nutrients and sediment. In contrast, removing stover for biofuels could increase soil erosion and therefore contribute to sediment pollution in waterways. Planting a perennial grass such as miscanthus and switchgrass in lieu of a corn/soybean rotation offers numerous environmental benefits, including reduced soil erosion and reduced nutrient loss.

Using the integrated land-use watershed-based eco-hydrological model, we empirically demonstrate tradeoffs between the preceding crop outputs that can be produced in a typical agricultural watershed in the U.S. Corn Belt. We create a production-possibility frontier using an evolutionary algorithm to identify the tradeoff frontier between the cost of alternative land uses and the set of outputs. ${ }^{2}$ We then identify the optimal (highest valued) allocation of land and set of outputs under a range of output prices. We investigate how the efficient allocation changes with different food and energy prices and how the allocation further changes when prices for water quality are considered.

Finally, we examine how closely the "marginal land" rule approximates the first best allocation under alternative prices. This exercise is meant to demonstrate the issues and tradeoffs involved with simple land-allocation rules such as limiting biofuel crop production to marginal land. It is not intended to provide a definitive answer to the optimal land use for this watershed. Instead, we are primarily interested in how sensitive the optimal land use is to changes in market prices and to the inclusion of nonmarket prices. So, while we do not include all outputs associated with alternative land uses (such as carbon sequestration, wildlife habitat, and biodiversity), inclusion of two market outputs, food and fuel, and two environmental

2 Cost is not typically depicted as a component of a production-possibility frontier. However, if cost is thought of as a reduction in a numeraire, the production-possibility-frontier interpretation holds. 


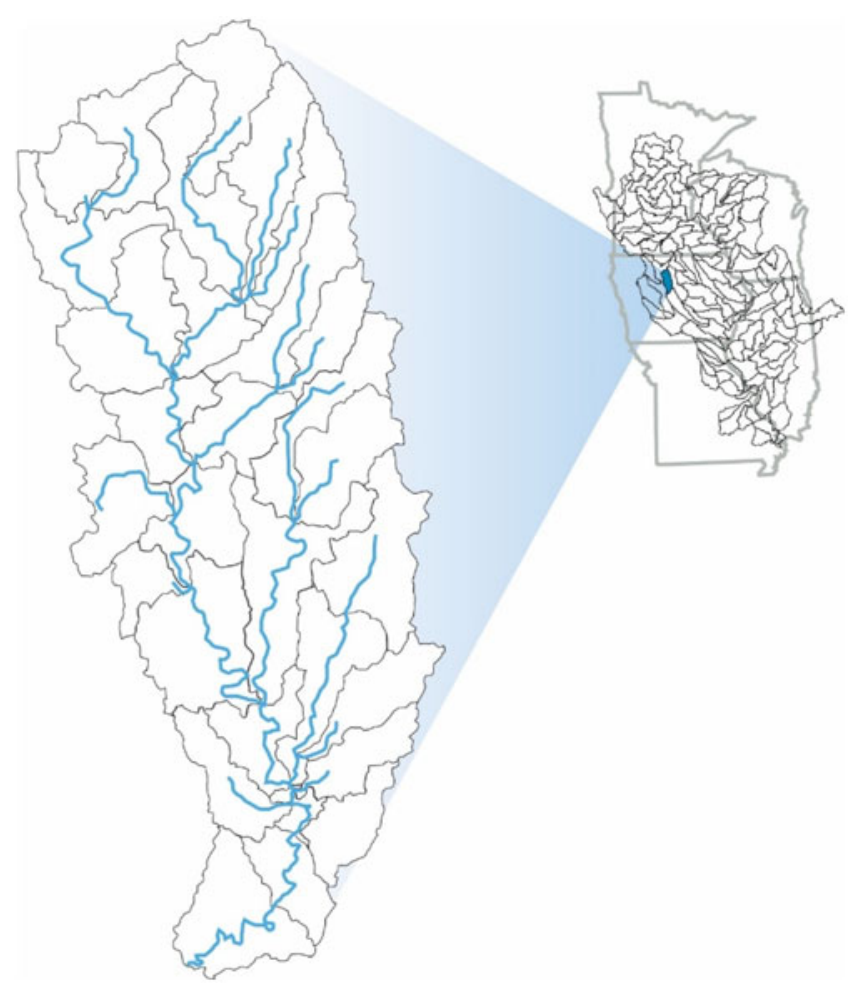

Figure 1. The Boone River Watershed in Iowa

outputs, nitrogen and sediment in water, allows us to consider tradeoffs between market and nonmarket goods.

\section{Empirical Application: The Boone River Watershed}

We study the watershed of the Boone River in northcentral Iowa (see Figure 1), an area with a high concentration of agricultural land that drains 237,000 hectares (585,640 acres), about 90 percent of which is planted to corn and soybeans. The Boone River runs through the center of the watershed and is heavily impacted by nutrient run-off from the surrounding agricultural landscape. Various targets for improved water quality in the river have been identified. There are total maximum daily loads (TMDLs), which are target water quality improvement goals, established for four waterbodies. ${ }^{3}$ However, the high level of nitrate in the stream system and Iowa's stated goal

3 See www.nrcs.usda.gov/Internet/FSE_DOCUMENTS/nrcs142p2_006983.pdf. 
of reducing its nitrogen export by about 40 percent to meet goals for addressing hypoxia in the Gulf of Mexico result in nitrate being the most salient target. Improvements at the watershed level would improve the health of the ecosystem and help meet conservation goals of the Nature Conservancy (Nature Conservancy 2012). The Boone River is a tributary of the Des Moines River, a key source of water for the Des Moines metropolitan area.

To depict how differences in agricultural land use (crop choices and management practices) affect water quality, we use the Soil and Water Assessment Tool (SWAT) (Arnold et al. 1998, Arnold and Fohrer 2005) ecohydrologic model to represent empirically biophysical and hydrologic aspects of the watershed. This model is well-suited to our purposes. Once a model is developed for a particular location (e.g., the Boone River watershed), it can simulate a wide range of changes in land use at specific locations within the watershed and predict how those changes will affect water quality at the watershed's exit. The model has a long history of use and has been used successfully worldwide across many watershed scales and conditions (Gassman et al. 2007, 2014, Krysanova and White 2015).

The model of the watershed is constructed using detailed data on agricultural land uses (e.g., crops grown, management practices applied, conservation practices used, and fertilizers applied) and physical characteristics (e.g., soils, slopes, and weather) and calibrated to water flow and nutrient loads in the rivers and streams in the watershed. The data for the model come from multiple sources, which are described in detail, along with the calibration methods, in Gassman (2008). An earlier version of this model used in Kling (2011) and Rabotyagov, Valcu-Lisman, and Kling (2016) provides another example.

In the SWAT modeling framework, the Boone River watershed is delineated into 30 sub-basins, which are further subdivided into 2,122 hydrological response units (HRUs). Each HRU represents a homogeneous area of topography, soil characteristics, land use, and management. The current baseline for the watershed is calibrated using monthly stream-flow nutrient data and incorporating earlier calibration efforts (Gassman 2008, Valcu-Lisman et al. 2016). ${ }^{4}$ The baseline testing of the SWAT monthly and annual predicted stream flows and pollutant loads are reported in Valcu-Lisman et al. (2016). The graphical results and statistics reported there indicate that SWAT accurately replicated annual and monthly stream-flow patterns across the simulation period.

Once the model is calibrated, it can be used to evaluate a large number of counterfactual patterns of land use and management for their effect on water quality. In our application, we are interested in evaluating tradeoffs between

\footnotetext{
4 The SWAT simulations in this study were performed with updated SWAT version 2012 code (SWAT2012, Release 615), which contains improved algorithms that more correctly simulate movement of nitrate through subsurface tile lines and other enhancements that were not present in the SWAT2005 code.
} 
a set of outputs associated with alternative land uses: food production, fuel production, and water quality production. As noted, there are multiple ways in which these three outputs can be produced. Food is produced by soybean and corn grains; thus, as more land in the watershed is planted to those crops, more food will be produced. Fuel can be produced via corn grain (traditional ethanol) or, potentially, through cellulosic conversion of stover. Removal of stover has negative consequences for water quality (nitrogen and sediment). Cellulosic ethanol can also be produced from switchgrass and miscanthus, which are often referred to as "dedicated biofuel crops." Improved water quality can be produced within a traditional corn-soybean system by adding cover crops or reducing tillage. Finally, the dedicated biofuel crops significantly improve water quality relative to a traditional corn-soybean system.

Table 1 summarizes the set of agricultural practices and land-use options and whether food, biofuel, and water quality improvements are associated with them. The cost for each option is drawn from a variety of sources (Gramig et al. 2013, Khanna, Dhungana, and Clifton-Brown 2008). The costs are constructed as additional to the baseline activity-the cost for the baseline activity is zero. We draw from the existing literature to identify the rates of conversion of corn grain, corn stover, miscanthus, and switchgrass biomasses to ethanol. Table 2 presents the conversion rates used in our study and the sources of each rate.

We study fourteen possible land-use options for each location in the watershed. Our model, combined with costs and various output prices for market goods (food and fuel), can be used to determine the market value associated with any particular assignment of one of these fourteen land uses to the 2,122 HRUs in the watershed. Furthermore, by selecting nonmarket values from the literature for water quality improvements via reductions in nitrogen emissions and soil erosion, we can estimate the total social value of the watershed including both market and nonmarket goods. However, solving for the highest valued land use in the watershed is nontrivial because of both a combinatorial challenge (with 2,122 HRUs and 14 options, there are $14^{\wedge} 2,122$ potential solutions to evaluate) and an interdependence issue: the effect of a type of land use on downstream water quality in one location depends on choices at other locations.

To address this optimization challenge, we take advantage of the tools of evolutionary algorithms. These algorithms provide an approach to dealing with the combinatorial nature of the watershed simulation-optimization model (Deb 2001). The heuristic global search algorithms intelligently search over the possible solutions. Deb (2001) provides general background information on evolutionary algorithms, and Rabotyagov et al. (2010) and Nicklow et al. (2010) discuss some recent applications of the algorithms to watershed optimization. Specifically, we take advantage of Strength Pareto Evolutionary Algorithm 2 (Zitzler, Laumanns, and Thiele 2002) as described in Rabotyagov et al. (2010) to approximate solutions to a five-objective Pareto optimization problem: maximize food and fuel production, minimize 
Table 1. Food, Fuel, and Water-quality Land-use Scenarios

\begin{tabular}{|c|c|c|c|c|c|}
\hline Scenario & $\begin{array}{l}\text { Food / } \\
\text { Source }\end{array}$ & $\begin{array}{l}\text { Biofuel / } \\
\text { Source }\end{array}$ & $\begin{array}{l}\text { Water Quality } \\
\text { Nitrogen / } \\
\text { Expected } \\
\text { Improvement }\end{array}$ & $\begin{array}{c}\text { Water } \\
\text { Quality } \\
\text { Sediment / } \\
\text { Expected } \\
\text { Improvement }\end{array}$ & Cost \\
\hline Miscanthus & No & Biomass & Yes & Yes & $\$ 59.0$ per ton \\
\hline Switchgrass & No & Biomass & Yes & Yes & $\$ 89.0$ per ton \\
\hline Baseline food & Grain & No & No change & No change & 0 \\
\hline $\begin{array}{l}\text { Baseline food, no } \\
\text { till }\end{array}$ & Grain & No & No & Yes & $\$ 6.7$ per acrea \\
\hline $\begin{array}{l}\text { Baseline food, } \\
\text { cover crops }\end{array}$ & Grain & No & Yes & Yes & $\$ 35.0$ per acreb \\
\hline $\begin{array}{l}\text { Baseline food, no } \\
\text { till and cover } \\
\text { crops }\end{array}$ & Grain & No & Yes & Yes & $\$ 41.7$ per acre \\
\hline Baseline fuel & No & Grain & No change & No change & 0 \\
\hline $\begin{array}{l}\text { Baseline fuel, no } \\
\text { till }\end{array}$ & No & Grain & No & Yes & $\$ 6.7$ per acre \\
\hline $\begin{array}{l}\text { Baseline fuel, } \\
\text { cover crops }\end{array}$ & No & Grain & Yes & Yes & $\$ 35.0$ per acre \\
\hline $\begin{array}{l}\text { Baseline fuel, no } \\
\text { till and cover } \\
\text { crops }\end{array}$ & No & Grain & Yes & Yes & $\$ 41.7$ per acre \\
\hline $\begin{array}{l}\text { Baseline food, } \\
\text { stover }\end{array}$ & Grain & Stover & No & No & $\$ 152.1$ per acrec \\
\hline $\begin{array}{l}\text { Baseline fuel, } \\
\text { stover }\end{array}$ & No & $\begin{array}{l}\text { Grain and } \\
\text { stover }\end{array}$ & No & No & $\$ 152.1$ per acre \\
\hline $\begin{array}{l}\text { Baseline food, } \\
\text { stover, no till }\end{array}$ & Grain & Stover & No & No & $158.8 \$$ per acre \\
\hline $\begin{array}{l}\text { Baseline fuel, } \\
\text { stover, no till }\end{array}$ & No & $\begin{array}{l}\text { Grain and } \\
\text { stover }\end{array}$ & No & No & $158.8 \$$ per acre \\
\hline
\end{tabular}

Sources: The costs for miscanthus and switchgrass come from Khanna, Dhungana, and Clifton-Brown (2008). The costs for baseline food and no-till come from Ag Decision Maker "Conservation Practices for Landlords," Iowa State University (2015). The cost for baseline food and cover crops comes from Iowa Nutrient Reduction Strategy, and the cost for baseline food stover comes from Gramig et al. (2013).

nitrogen and sediment loads in the water, and minimize the cost of each alternative management option.

We describe the results of this Pareto optimization and evaluate points on the frontier using several sets of market prices for food and fuel and nonmarket prices for water quality outputs to determine the highest valued landscape configuration under each set of prices. We further examine the sensitivity of these findings to changes in relative prices and compare the highest valued configurations to those that would be prescribed by limiting production of biofuel crops to marginal land. 
Table 2. Ethanol Conversion Rates

Conversion Rate to Ethanol in Gallons per Ton

Corn grain

115

Corn stover

Switchgrass

100

Miscanthus

90

\section{Results and Discussion}

\section{Pareto Efficient Choices}

We combine the optimization framework and our simulation model to evaluate counterfactual watershed scenarios based on the fourteen land-use choices in terms of estimated costs, food production (corn grain), fuel output, and their effect on water quality (total nitrogen load and sediment) over a six-year period (1995-2001). Thus, we approximate a five-objective Pareto frontier: cost, fuel production, food production, mean nitrogen loads, and mean sediment loads. To approximate the Pareto frontier, we start by simulating watershed scenarios in which each field is assigned the same land use (cases denoted as uniform scenarios). Table 3 summarizes the results of those scenarios.

As expected, the bioenergy crop scenarios (switchgrass and miscanthus) are the most expensive but yield the highest fuel outputs and the largest water quality improvements. Stover removal and cover crops have slightly positive impacts on the total corn yields while no-till management has a small negative impact on total yields. Stover removal has a small but negative impact on water quality (the loads of both nitrogen and sediment increase). No-till management has a small negative impact on the total nitrogen load but also has a large positive impact on the sediment loads. Finally, cover crops have a positive impact on water quality, generating large reductions in both nitrogen and sediment loads.

The optimization algorithm uses the 14 scenarios and an additional set of 46 random scenarios as a first step in constructing the Pareto frontier. In brief, the algorithm starts by Pareto-comparing the outputs of the initial 60 watershed configurations. Configurations that are dominated by others-one or more of the outputs can be produced at higher levels without reducing production of any other output-are removed from consideration. The rest are combined to create new configurations that the algorithm Pareto-compares to the initial set. This process continues until a stopping rule is met. Details regarding how existing configurations are intelligently combined to create new ones for consideration can be found in Zitzler, Laumanns, and Thiele (2002). 
Table 3. Food, Fuel, and Water-quality Uniform Land-use Scenarios

\begin{tabular}{|c|c|c|c|c|c|}
\hline & Cost & Ethanol & Food & Nitrogen Reduction & $\begin{array}{l}\text { Sediment } \\
\text { Reduction }\end{array}$ \\
\hline Land Use & Million Dollars & Million Gallons & Million Tons & Percent & Percent \\
\hline Switchgrass & 270.22 & 275.73 & 0.00 & 60.53 & 85.94 \\
\hline Miscanthus & 308.67 & 470.85 & 0.00 & 88.05 & 88.65 \\
\hline Baseline food & 0.00 & 0.00 & 1.21 & 0.00 & 0.00 \\
\hline Baseline food, no till & 3.58 & 0.00 & 1.18 & $(0.83)$ & 73.06 \\
\hline Baseline food, cover crops & 18.69 & 0.00 & 1.25 & 56.22 & 34.67 \\
\hline Baseline food, no till and cover crops & 22.27 & 0.00 & 1.24 & 60.75 & 76.32 \\
\hline Baseline fuel & 0.00 & 138.63 & 0.00 & 0.00 & 0.00 \\
\hline Baseline fuel, no till & 3.58 & 135.82 & 0.00 & $(0.83)$ & 73.06 \\
\hline Baseline fuel, cover crops & 18.69 & 143.87 & 0.00 & 56.22 & 34.67 \\
\hline Baseline fuel, no till and cover crops & 22.27 & 142.78 & 0.00 & 60.75 & 76.32 \\
\hline Baseline food, stover & 81.24 & 52.64 & 1.24 & $(0.73)$ & $(3.69)$ \\
\hline Baseline fuel, stover & 81.24 & 194.76 & 0.00 & $(0.73)$ & $(3.69)$ \\
\hline Baseline food, stover, no till & 84.82 & 51.82 & 1.22 & $(0.41)$ & 73.21 \\
\hline Baseline fuel, stover, no till & 84.82 & 191.72 & 0.00 & $(0.41)$ & 73.21 \\
\hline
\end{tabular}




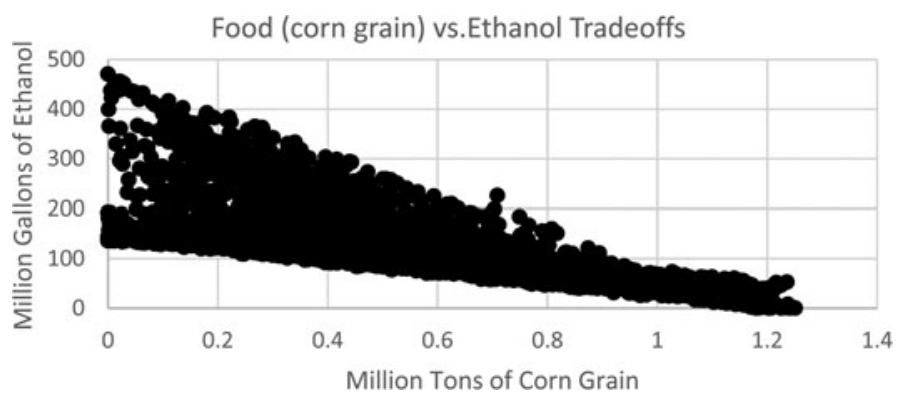

Figure 2a. Food/Fuel Tradeoffs

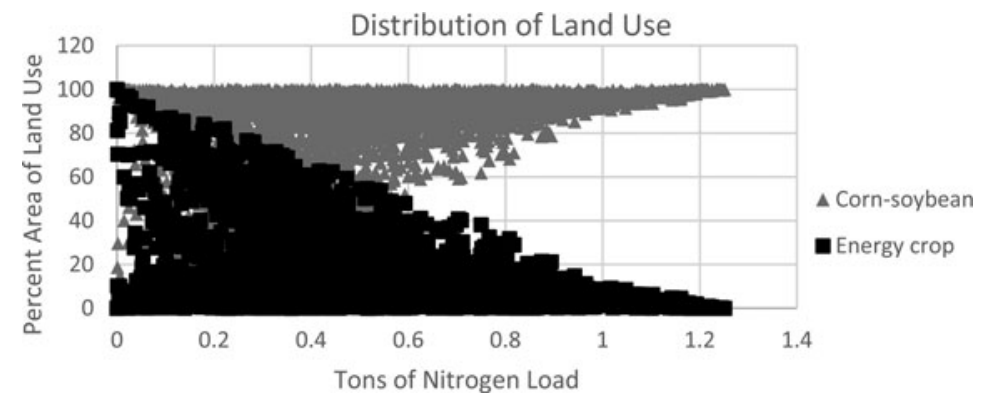

Figure 2b. Land-use Distribution vs. Food

In our application, the final frontier contains more than 8,400 unique watershed configurations of fuel, food, cost, and water quality (mean nitrogen and sediment loads) that are not Pareto-dominated by any other configuration. The frontier can also be viewed as a production-possibility frontier between the four outputs and the cost.

The Pareto frontier offers valuable information regarding the nature of efficient tradeoffs between the five outputs. Since it is difficult to visualize tradeoffs across five dimensions, we present pairwise projections of the Pareto frontier to illustrate the food/ethanol and ethanol/water-quality tradeoffs. Figure 2a depicts the food/fuel tradeoffs. Overall, we find an inverse linear relationship between food and fuel. As food outputs increase, fuel outputs decrease. However, for any given food output, there are multiple watershed configurations (drawn as vertical lines) with different fuel outputs. The ranges of fuel output are larger for smaller food outputs and smaller for larger food outputs. Similarly, for any given fuel output (drawn as horizontal lines), there are multiple watershed configurations with food output varying from low to high.

Figure $2 \mathrm{~b}$ relates the food/fuel trends to the distribution of land-use options. When the output of food is low, fuel can be obtained from corn only, corn and 


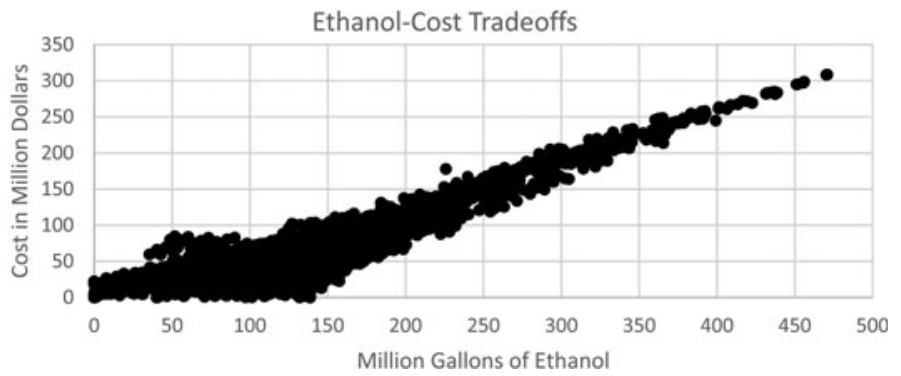

Figure 3a. Fuel/Cost Tradeoffs

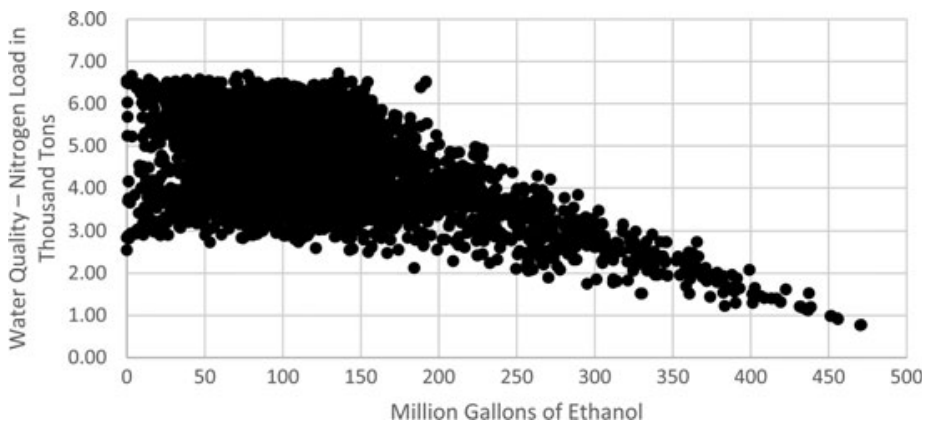

Figure 3b. Fuel/Water-quality Tradeoffs

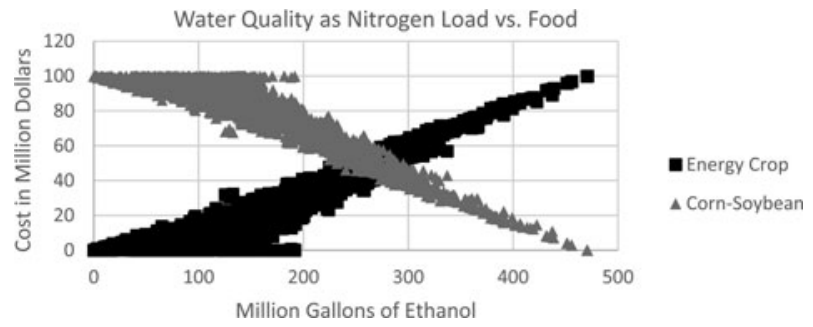

Figure 3c. Distribution of Land Use

stover, stover only, or bioenergy crops. The figure summarizes the distribution of the energy and corn-soybean-based crops as a percentage of total area. As shown, when the output of food is low, use of bioenergy crops ranges from 0 to 100 percent. This implies that, when use of the bioenergy crops is low, the fuel associated with a low quantity of food is the result of corn grain 
conversion to ethanol. When use of the bioenergy crops is high, the fuel output is the result of bioenergy crop conversion to fuel. As the quantity of food produced increases, the bioenergy crop use decreases and fuel is obtained either from corn grain or conversion of stover.

Figure 3a depicts the fuel/cost tradeoffs. In general, cost increases as fuel output increases; higher costs are associated with greater use of energy crops (see Figure 3c). Figure 3b depicts the fuel/water quality tradeoffs (total nitrogen load). Higher fuel outputs are associated with lower total nitrogen loads (better water quality). The improved water quality is also explained by increased use of the bioenergy crops. As with the food/fuel tradeoff, for any given fuel quantity there are multiple watershed configurations that achieve different levels of water quality, and for any level of water quality there are multiple configurations that achieve different fuel quantities (see the dense area in Figure $3 \mathrm{~b}$ for fuel of less than 150 million gallons). The configurations that achieve less than 150 million gallons have a higher use of the cornsoybean-based crop (Figure 3c). All three figures show a turning point at about 150 million gallons when production of bioenergy crops increases dramatically. This implies that, above that level, most of the fuel is obtained as the result of the conversion of corn-soybean crops to bioenergy crops.

Next, we evaluate the solutions on the Pareto frontier using several sets of market prices for food and fuel and nonmarket prices for water quality outputs to determine the highest valued landscape configurations under a range of prices. We then compare these values with the values of the watershed configurations where the production of energy crops is limited to marginal land.

We recognize that additional environmental services such as provision of wildlife habitat, biodiversity, and carbon sequestration, may be associated with the energy crops and potentially affect the optimal land allocations. Although we do not include such benefits in the optimization, we provide an ex post optimization sensitivity analysis in which we vary the nonmarket prices for water quality benefits associated with the energy crops and consider the additional carbon-sequestration benefits. Before presenting the results of these comparisons, we describe the watershed configurations associated with different definitions of marginal land.

\section{Marginal Land}

We use four Soil Survey Geographic (SSURG0) definitions (Natural Resources Conservation Service 2015) to identify marginal land in the watershed: slope gradient, erosion class, land capability class, and soil tolerance factor. The erosion class (four categories) defines the maximum amount of wind or water erosion at which soil productivity can be maintained. The soil tolerance factor represents the maximum rate of annual erosion at which crop productivity can be sustained economically. It takes a value of 1 to 5 tons per acre per year in which a factor of 1 denotes shallow or fragile soils and a factor of 5 denotes soils that are least subject to erosion. In the Boone 
River watershed, 5 is the predominant factor. The soil capability classes represent suitability of the soils for field crops on a scale of 1 through 8 in which lower numbers identify soils with fewer limitations.

We follow standard definitions of marginal land as defined by these metrics. Specifically, we identify the marginal land as the HRUs characterized by (i) a slope gradient of greater than 5 percent, (ii) erosion class 2, (iii) land capability class 3 or greater, or (iv) a tolerance soil factor of 3 or less. Additionally, we consider the case in which at least one definition is met. Regardless of the definition used, less than 9 percent of the crop area in the watershed is marginal land (see Table 4, column 2). Also, there is some overlap for the four definitions of marginal land (some HRUs are identified as marginal land under more than one definition). Figure 4 depicts the spatial distribution of marginal land in the watershed in 50-acre units.

For each of the five definitions of marginal land, Table 4 summarizes food, fuel, and water quality production when miscanthus is used on marginal land and the baseline activity of corn-soybean production is maintained on the rest of the land. Fuel production associated with miscanthus biomass is summarized in column three (million gallons). Crop production (corn and soybeans in million tons) is summarized in columns four and five. Details on water quality changes (total nitrogen and sediment) expressed as percent improvements relative to the baseline can be found in columns six and seven. As expected, we find that ethanol production is directly related to the percentage of an area devoted to biofuel crops.

To better understand the relative efficiency of the solutions, we compare outcomes when all of the definitions of marginal land are met with outcomes of optimal solutions that are similar in terms of production of food (total corn), water quality, or fuel (see Table 5). For example, the optimal Pareto solution that results in the same amount of food production (second row of Table 5) generates less than half as much fuel and makes a smaller reduction in nitrogen but significantly reduces the amount of sediment. Alternatively, the optimal solution that generates the same amount of fuel (fourth row of Table 5) provides a similar food outcome but yields better water quality outcomes both in terms of nitrogen and sediment.

Another interesting point of comparison is the watershed configuration from the frontier that allocates the same share of land to miscanthus as the arbitrary marginal-land option (final row of Table 5). Interestingly, this Pareto-efficient solution has a different spatial allocation; most of the area allocated to miscanthus is in a single sub-basin (see Figure 5). In fact, less than 10 percent of the area allocated to the bioenergy crop can be identified as marginal land under any of the definitions.

\section{Highest Valued Land Allocations}

Next, we apply prices and nonmarket values for water quality outputs to compare the total value provided by the most efficient solutions (those on 
Table 4. Marginal Land: Food, Fuel, and Water Quality

\begin{tabular}{|c|c|c|c|c|c|c|}
\hline \multirow[b]{3}{*}{ Marginal Land Criteria } & \multirow{3}{*}{$\begin{array}{l}\text { Energy Crop } \\
\text { Percent Area }\end{array}$} & \multicolumn{3}{|c|}{ Ethanol and Food } & \multicolumn{2}{|c|}{ Water Quality Change } \\
\hline & & Ethanol & Corn & Soybean & Nitrogen & Sediment \\
\hline & & Million Gallons & Million Tons & Million Tons & Percent & Percent \\
\hline Slope & 1.43 & 6.25 & 1.19 & 0.31 & 2.88 & 12.86 \\
\hline Erosion & 2.91 & 13.13 & 1.17 & 0.31 & 4.07 & 11.26 \\
\hline Land capability class & 4.00 & 18.24 & 1.16 & 0.31 & 5.31 & 14.43 \\
\hline Soil tolerance factor & 4.44 & 18.91 & 1.15 & 0.3 & 4.24 & 3.62 \\
\hline All & 8.91 & 39.13 & 1.10 & 0.29 & 10.65 & 18.17 \\
\hline
\end{tabular}




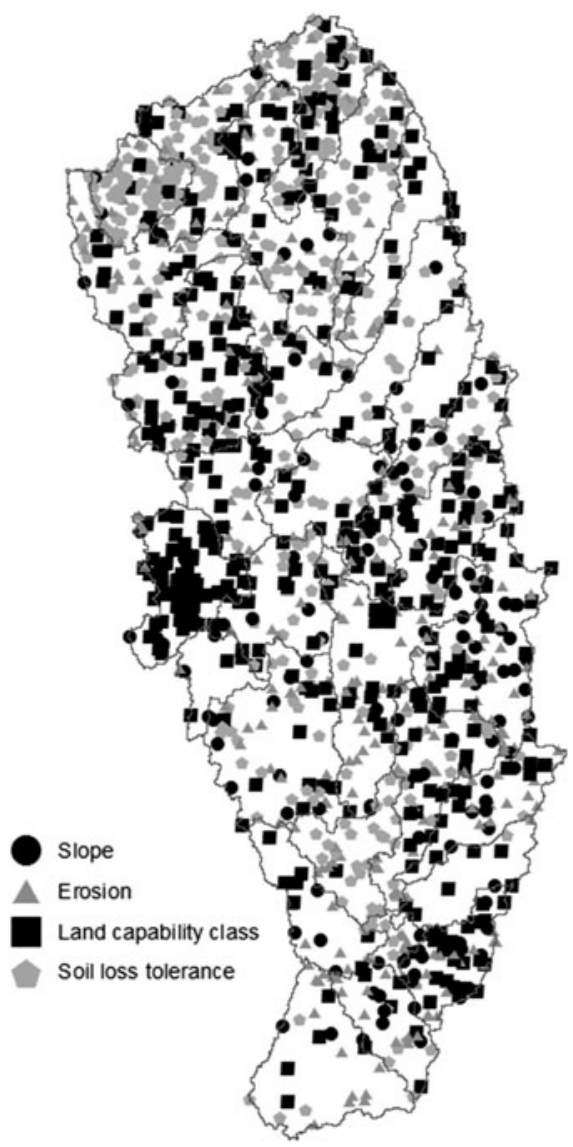

\section{Figure 4. Spatial Distribution of Marginal Land in the Watershed}

Note: Each dot represents 50 acres.

the Pareto frontier) with the marginal-land solutions. In this way, we can determine whether the marginal land solutions are significantly less valuable than points along the frontier or whether the marginal land dictate provides an approximately optimal rule to maximize the value of the watershed. To aid in this analysis, for each watershed configuration we determine two sets of total values: one that relies solely on the market prices for food and fuel and one that includes nonmarket prices for water quality outputs. ${ }^{5}$

Total value is determined by valuing the food and fuel outputs at four sets of market prices and subtracting the total cost associated with that watershed

\footnotetext{
5 Although we did not include this set in the optimization, we included the soybean outputs associated with the corn-soybean crop choice when determining the total values.
} 
Table 5. Marginal Land vs. Similar Pareto Efficient Solutions

\begin{tabular}{lccccc}
\hline & Energy Crop & Ethanol & Corn & Nitrogen Reduction & Sediment Reduction \\
\cline { 2 - 6 } Marginal Land & Percent Area & Million Gallons & Million Tons & Percent & Percent \\
\hline Marginal land (all) & $\mathbf{8 . 9}$ & $\mathbf{3 9 . 1}$ & $\mathbf{1 . 1}$ & $\mathbf{1 0 . 7}$ & $\mathbf{1 8 . 2}$ \\
Food (corn) & 1.6 & 15.1 & $\mathbf{1 . 1}$ & 1.2 & $\mathbf{1 0 . 0}$ \\
Water quality & 3.08 & 45.8 & 0.9 & 1.0 & $\mathbf{1 8 . 3}$ \\
Ethanol & 3.5 & $\mathbf{3 9 . 2}$ & 0.4 & 27.6 & 31.7 \\
Same acreage & $\mathbf{9 . 0}$ & 132.5 & 27.6 & 31.7 \\
\hline
\end{tabular}




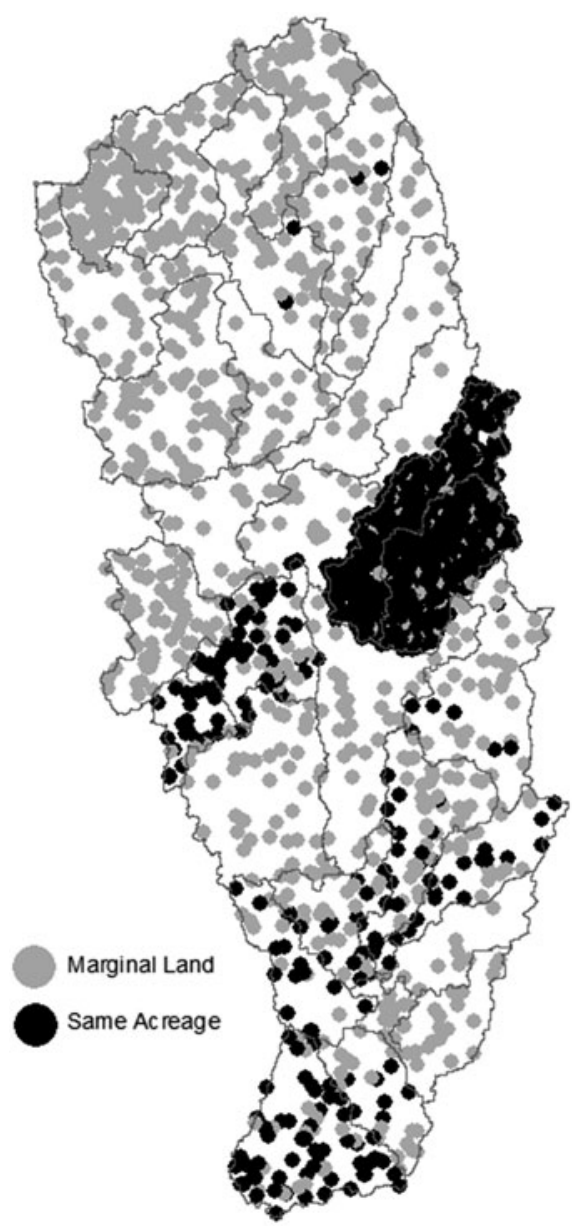

Figure 5. Spatial Distribution of the Marginal-land and Pareto Solutions for the Same Acreage

Note: Each dot equals 50 acres.

configuration. The prices correspond to historical market prices: ${ }^{6}$ (i) prices available in September 2015 (\$3.68 per bushel of corn, \$1.61 per gallon of ethanol, and $\$ 9.05$ per bushel of soybeans), (ii) the lowest fuel price for 1995 through 2015 and its paired corn and soybean prices $(\$ 1.97$ per bushel of

\footnotetext{
6 The prices for corn are from the National Agricultural Statistics Service Quick Stats database (http://quickstats.nass.usda.gov). The fuel prices are reported by the Nebraska Energy Office (www.neo.ne.gov/statshtml/66.html).
} 
Table 6a. Quantity Outcomes for the Highest Valued Pareto Solutions for Market Value Only

\begin{tabular}{|c|c|c|c|c|c|c|c|c|c|c|}
\hline \multicolumn{3}{|c|}{ Market Price } & \multicolumn{3}{|c|}{ Distribution Land Use } & \multicolumn{3}{|c|}{ Ethanol and Food } & \multicolumn{2}{|c|}{ Water Quality Change } \\
\hline Corn & Ethanol & Soybeans & $\begin{array}{l}\text { Energy } \\
\text { Crop }\end{array}$ & $\begin{array}{c}\text { Corn / } \\
\text { Soybeans }\end{array}$ & $\begin{array}{c}\text { Conservation } \\
\text { Practices }\end{array}$ & Ethanol & Corn & Soybeans & $\begin{array}{c}\text { Nitrogen } \\
\text { Reduction }\end{array}$ & $\begin{array}{l}\text { Sediment } \\
\text { Reduction }\end{array}$ \\
\hline $\begin{array}{c}\text { Dollars } \\
\text { per } \\
\text { Bushel }\end{array}$ & $\begin{array}{c}\text { Dollars } \\
\text { per } \\
\text { Gallon }\end{array}$ & $\begin{array}{c}\text { Dollars } \\
\text { per } \\
\text { Bushel }\end{array}$ & Percent & Percent & Percent & $\begin{array}{l}\text { Million } \\
\text { Gallons }\end{array}$ & $\begin{array}{l}\text { Million } \\
\text { Tons }\end{array}$ & $\begin{array}{l}\text { Million } \\
\text { Tons }\end{array}$ & Percent & Percent \\
\hline 3.68 & 1.61 & 9.05 & 100 & 0 & 0 & 470.85 & 0.00 & 0.00 & 88.05 & 88.65 \\
\hline 1.97 & 0.9 & 4.44 & 0 & 100 & 0 & 138.63 & 0.00 & 0.32 & 0.00 & 0.00 \\
\hline 7.63 & 2.71 & 16.2 & 100 & 0 & 0 & 470.85 & 0.00 & 0.00 & 88.05 & 88.65 \\
\hline 2.14 & 3.58 & 5.62 & 100 & 0 & 0 & 470.85 & 0.00 & 0.00 & 88.05 & 88.65 \\
\hline
\end{tabular}


Table 6b. Quantity Outcomes for the Highest Valued Pareto Solutions for Market Value and Water-quality Value

\begin{tabular}{|c|c|c|c|c|c|c|c|c|c|c|}
\hline \multicolumn{3}{|c|}{ Market Price } & \multicolumn{3}{|c|}{ Land Use Distribution } & \multicolumn{3}{|c|}{ Ethanol and Food } & \multicolumn{2}{|c|}{ Water Quality Change } \\
\hline Corn & Ethanol & Soybean & $\begin{array}{l}\text { Energy } \\
\text { Crop }\end{array}$ & $\begin{array}{c}\text { Corn / } \\
\text { Soybeans }\end{array}$ & $\begin{array}{l}\text { Conservation } \\
\text { Practices }\end{array}$ & Ethanol & Corn & Soybeans & $\begin{array}{l}\text { Nitrogen } \\
\text { Reduction }\end{array}$ & $\begin{array}{l}\text { Sediment } \\
\text { Reduction }\end{array}$ \\
\hline $\begin{array}{c}\text { Dollars } \\
\text { per } \\
\text { Bushel }\end{array}$ & $\begin{array}{c}\text { Dollars } \\
\text { per } \\
\text { Gallon } \\
\end{array}$ & $\begin{array}{c}\text { Dollars } \\
\text { per } \\
\text { Bushel }\end{array}$ & & Percent & & $\begin{array}{l}\text { Million } \\
\text { Gallons }\end{array}$ & $\begin{array}{c}\text { Million } \\
\text { Tons }\end{array}$ & $\begin{array}{l}\text { Million } \\
\text { Tons }\end{array}$ & Percent & Percent \\
\hline 3.68 & 1.61 & 9.05 & 100 & 0 & 0 & 470.85 & 0.00 & 0.00 & 88.05 & 88.65 \\
\hline 1.97 & 0.9 & 4.44 & 0 & 100 & 100 & 143.87 & 0.00 & 0.32 & 56.22 & 34.67 \\
\hline 7.63 & 2.71 & 16.2 & 100 & 0 & 0 & 470.85 & 0.00 & 0.00 & 88.05 & 88.65 \\
\hline 2.14 & 3.58 & 5.62 & 100 & 0 & 0 & 470.85 & 0.00 & 0.00 & 88.05 & 88.65 \\
\hline
\end{tabular}


corn, $\$ 0.9$ per gallon of ethanol, and $\$ 4.44$ per bushel of soybeans), (iii) the highest fuel price for 1995 through 2015 and its paired corn and soybean prices ( $\$ 2.14$ per bushel of corn, $\$ 3.58$ per gallon of ethanol, and $\$ 5.62$ per bushel of soybeans), and (iv) the highest corn price and its paired fuel and soybean prices ( $\$ 7.63$ per bushel of corn, $\$ 2.72$ per gallon of ethanol, and $\$ 16.20$ per bushel of soybeans) for the same period. We value the water quality benefits at $\$ 4.93$ per reduced ton of sediment (Natural Resources Conservation Service 2009) and $\$ 3.13$ per reduced pound of nitrogen (Ribaudo, Savage, and Aillery 2014). ${ }^{7}$

Tables $6 \mathrm{a}$ (market prices only) and $6 \mathrm{~b}$ (market and nonmarket prices) present the outcomes for the highest valued solutions in terms of output of food, fuel, and water quality outputs. In all cases, the highest valued land-use configuration consists of all land in the watershed being used the same way. Except for the case where the fuel price is set at its lowest level, the highest valued outcome comes from growing the bioenergy crop (miscanthus) on all land in the watershed. In these cases, the water quality improvements are at their highest levels. When the fuel price is lowest ( $\$ 0.90$ per gallon) and water quality improvements are not valued, corn-soybean production is the chosen land-use option with corn grain used for fuel production (see Table 6a). Since no additional conservation measures are taken, there are no changes in water quality. However, when water quality improvements are valued using the same set of prices (low fuel), corn-soybean production remains the dominant landuse option, but cover crops are used in every field as the conservation practice (see Table 6b). Thus, when valuing the nonmarket outputs, it is socially optimal to change the land use by adding cover crops but it is not socially optimal to undertake the larger change of converting production to miscanthus, which is much more costly than cover crops.

Relative to the marginal-land scenarios, all of the market-price optimal solutions that involve production of miscanthus provide significantly greater fuel and water-quality outcomes (see Table 7). The magnitudes of the differences range from 1.24 when the fuel price is lowest to 5.17 when the fuel price is highest. Valuing water quality improvements increases the total values but the range of the differences is similar. Thus, if biofuel production is restricted to marginal land, the value of the resulting outputs could be as much as five times less. These results are highly sensitive to the relevant prices.

Nonmarket values for water quality are poorly understood, and the results of our analysis are likely to be sensitive to the values used. To test this sensitivity, we conducted the same analysis using values twice as high as the original ones and found no change in the optimal outcomes.

\footnotetext{
7 Detailed information about how these estimates were obtained can be found in the cited reports. We use these estimates to value the improvements in water quality (reduced nitrogen and sediment).
} 
Table 7. Marginal Land Value and the Highest Valued Solutions

\begin{tabular}{|c|c|c|c|c|c|}
\hline \multicolumn{3}{|c|}{ Price } & & \multicolumn{2}{|c|}{$\begin{array}{c}\text { Total Value in Million } \\
\text { Dollars }\end{array}$} \\
\hline Corn & Ethanol & Soybeans & & & \\
\hline $\begin{array}{c}\text { Dollars per } \\
\text { Bushel }\end{array}$ & $\begin{array}{c}\text { Dollars per } \\
\text { Gallon }\end{array}$ & $\begin{array}{c}\text { Dollars per } \\
\text { Bushel }\end{array}$ & Land Use & Market & $\begin{array}{c}\text { Market and } \\
\text { Water Quality }\end{array}$ \\
\hline \multirow[t]{2}{*}{3.68} & 1.61 & 9.05 & $\begin{array}{l}\text { Marginal } \\
\text { land }\end{array}$ & 292.68 & 297.45 \\
\hline & & & Optimal & 449.40 & 488.81 \\
\hline \multirow[t]{2}{*}{1.97} & 0.9 & 4.44 & $\begin{array}{l}\text { Marginal } \\
\text { land }\end{array}$ & 141.94 & 146.71 \\
\hline & & & Optimal & 176.65 & 187.82 \\
\hline \multirow[t]{2}{*}{7.63} & 2.72 & 16.2 & $\begin{array}{l}\text { Marginal } \\
\text { land }\end{array}$ & 616.52 & 621.29 \\
\hline & & & Optimal & 967.34 & $1,006.75$ \\
\hline \multirow[t]{2}{*}{2.14} & 3.58 & 5.62 & $\begin{array}{l}\text { Marginal } \\
\text { land }\end{array}$ & 266.71 & 271.48 \\
\hline & & & Optimal & $1,376.98$ & $1,416.39$ \\
\hline
\end{tabular}

Next, we summarize the results of an extensive sensitivity analysis that considered the possibility that (i) the cost of biofuel production could be significantly higher than the cost of ethanol production and (ii) the energy crops could provide additional environmental services (such as habitat and carbon sequestration). We analyze how the highest valued land-use configurations change relative to the outcomes summarized in Tables $6 \mathrm{a}$ and $6 \mathrm{~b}$ when accounting for these possibilities. ${ }^{8}$

To consider the possibility that biofuel production costs may be higher than the cost of producing ethanol, we arbitrarily lower the prices for biofuel 1.2 to 2.0 times relative to the price for ethanol produced from corn and corn stover. The total values associated with the optimal solutions decrease as expected. However, the land-use configurations change in response to some of the variations. For example, setting the price for biofuel to half of the price for ethanol (decreasing the biofuel price by a factor of 2) changes the land use in all but one of the scenarios (the lowest ethanol price) from miscanthus on every field to corn-soybean production with the corn and stover used to produce fuel. Additionally, no-till management is used in every field as the choice of conservation practice. The use of no-till results in large reductions in sediment. Production of both ethanol and water quality decline relative to the original outcomes summarized in Tables $6 \mathrm{a}$ and $6 \mathrm{~b}$.

\footnotetext{
8 We provide only a qualitative summary of the sensitivity analysis. Numerical results are available per request.
} 
Bioenergy crops have the potential to enhance biodiversity by providing habitat for many species of wildlife and nesting for birds (Werling et al. 2014). To evaluate these additional ecosystem services, we double the nonmarket values only for the water quality benefits associated with the energy crops. The highest valued landuse option changes only when the fuel price is set at the lowest level: from uniform use of corn-soybean production where corn grain is used to produce fuel to production of the bioenergy crop (miscanthus) on every field in the watershed. As a result, the ethanol and water-quality outcomes improve relative to the initial values. There is no change in the values for the other fuel prices.

Bioenergy crops and conservation practices such as no-till management and use of cover crops have the potential to reduce GHG emissions through sequestration of carbon in the soil. Although numerous studies have provided estimates of carbon sequestration for these crops and conservation practices, concern arises regarding the consistency and suitability of those estimates for the Boone River watershed. Valcu (2013) used Environmental Policy Integrated Climate (EPIC) Model simulations to obtain carbon sequestration estimates for no-till and cover crops in the watershed but did not estimate carbon sequestration for switchgrass and miscanthus. We use estimates from Follett et al. (2012) in which a field experiment was used to measure carbon sequestration by switchgrass. We assume that our two energy crops have equal carbon-sequestration rates. We add carbon-sequestration benefits to our analysis by computing the corresponding carbon sequestration values for each watershed configuration on the Pareto frontier. We then transform those values into metric tons of carbon dioxide equivalent $\left(\mathrm{MtCO}_{2} \mathrm{e}\right)$ and evaluate them at average social costs of carbon of $\$ 12$ and $\$ 50 .{ }^{9,10}$

Inclusion of the carbon-sequestration benefit changes the highest valued land configuration only when the fuel price is at its lowest level. When the social cost of carbon is low, corn-soybean production with fuel produced from corn grain is used on all of the land in the watershed and cover crops and no-till are chosen for conservation practices. When the social cost of carbon is higher, the highest valued land-use configuration is characterized by production of the bioenergy crop (miscanthus). The water quality benefits improve under both social costs.

The results of the sensitivity analysis suggest that the optimal land-use configuration is sensitive to additional environmental benefits only when fuel prices are set at the lowest values. However, the output values from the sensitivity analysis are larger than the values obtained when bioenergy production was restricted to marginal land.

\footnotetext{
9 We use $\mathrm{MtCO}_{2} \mathrm{e}$ estimates of 0.67 for no-till, 0.62 for cover crops, 2.03 for cover crops and notill production (Valcu 2013), and 7.3 for the energy crop (Follett 2012). We assume that no $\mathrm{MtCO}_{2} \mathrm{e}$ is associated with stover removal. See https://www.whitehouse.gov/sites/default/files/omb/ inforeg/scc-tsd-final-july-2015.pdf.

10 Social cost of carbon: https://www.whitehouse.gov/sites/default/files/omb/inforeg/scc-tsdfinal-july-2015.pdf.
} 
Table 8. Quantity and Value Outcomes for the Food and Water-quality Targets

\begin{tabular}{|c|c|c|c|c|c|c|c|c|c|c|c|}
\hline \multirow[b]{3}{*}{ Target } & \multirow{2}{*}{\multicolumn{3}{|c|}{$\frac{\text { Land Use Distribution Area }}{\text { Percent }}$}} & \multirow{2}{*}{\multicolumn{2}{|c|}{$\begin{array}{c}\text { Fuel } \\
\text { Million Gallons }\end{array}$}} & \multirow{2}{*}{\multicolumn{2}{|c|}{$\begin{array}{c}\text { Food } \\
\text { Million Tons }\end{array}$}} & \multirow{2}{*}{\multicolumn{2}{|c|}{$\begin{array}{c}\begin{array}{c}\text { Water Quality } \\
\text { Reduction }\end{array} \\
\text { Percent }\end{array}$}} & \multirow{2}{*}{\multicolumn{2}{|c|}{$\frac{\text { Value }}{\text { Million Dollars }}$}} \\
\hline & & & & & & & & & & & \\
\hline & $\begin{array}{l}\text { Energy } \\
\text { Crop }\end{array}$ & Corn & $\begin{array}{l}\text { Corn } \\
\text { Stover }\end{array}$ & $\begin{array}{c}\text { Ethanol } \\
\text { Total }\end{array}$ & $\begin{array}{l}\text { Ethanol } \\
\text { Energy } \\
\text { Crop }\end{array}$ & Corn & Soybeans & Nitrogen & Sediment & $\begin{array}{l}\text { Market } \\
\text { Prices } \\
\text { Only }\end{array}$ & $\begin{array}{l}\text { Market } \\
\text { and } \\
\text { Water } \\
\text { Quality }\end{array}$ \\
\hline $\begin{array}{c}\text { Water-quality } \\
\text { solution A }\end{array}$ & 13.81 & 73.47 & 12.72 & 150.01 & 48.98 & 0.28 & 0.28 & 45.00 & 45.00 & 320.48 & 429.44 \\
\hline $\begin{array}{c}\text { Water-quality } \\
\text { solution B }\end{array}$ & 7.07 & 80.96 & 11.97 & 54.60 & 29.68 & 0.98 & 0.29 & 45.00 & 45.00 & 283.43 & 392.57 \\
\hline Food Solution & 8.5 & 72.00 & 19.04 & 96.62 & 32.76 & 0.65 & 0.29 & 28.07 & 41.35 & 297.75 & 325.80 \\
\hline
\end{tabular}




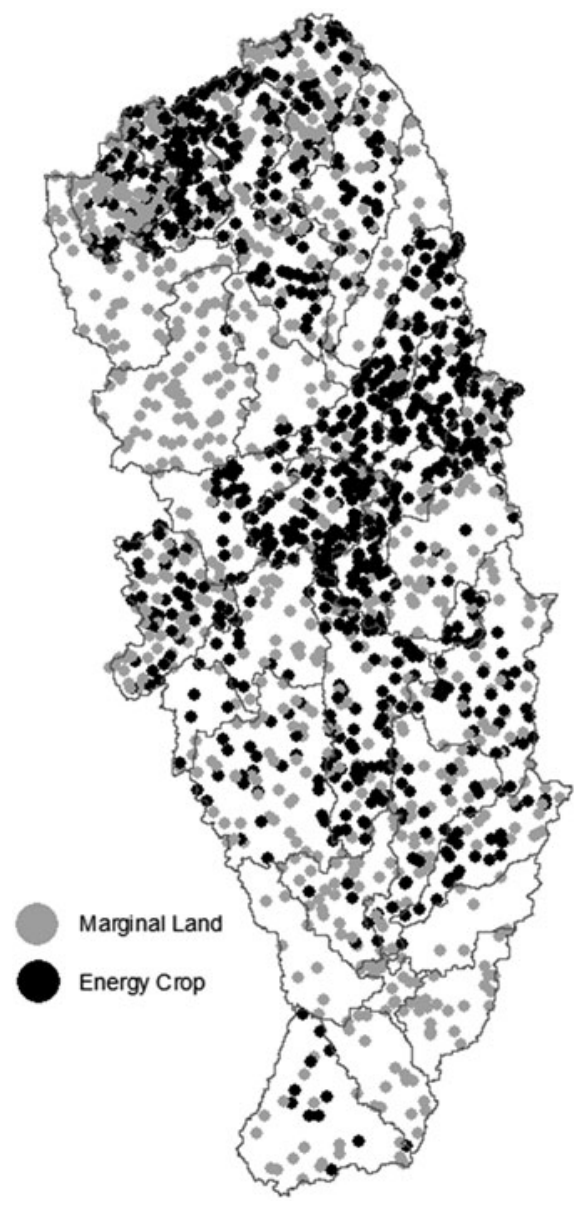

Figure 6. Land-use Distribution When Corn Grain Is Set to 53 Percent of Baseline Corn Production

Finally, we analyze the values associated with solutions that achieve (i) a 45 percent reduction in nitrogen and in sediment and (ii) food production equivalent to 53 percent of the baseline corn production of 1.21 million tons and report the results in Table 8. The water quality goal of 45 percent reductions corresponds to an overall goal set under the Iowa Reduction Nutrient Strategy. The second solution corresponds roughly to the existing land use-47 percent of the state's corn production is used for fuel production. ${ }^{11}$ We limit our valuation to the September 2015 prices.

11 See www.iowacorn.org/index.cfm?nodeID=30316. 
Two Pareto-optimal solutions achieve a 45 percent reduction in both nitrogen and sediment loads. However, the total food, fuel, and total values in the two solutions are different (see Table 8). Solution A produces more fuel (150 million gallons) with one-third of the total fuel outcome obtained from the bioenergy crops, produces less food ( 0.28 million tons of corn), and achieves a higher total value ( $\$ 320$ million for market values only). Solution B produces significantly more food (0.98 million tons of corn) but less fuel (54.6 million gallons), more than half of which comes from the bioenergy crops, and achieves a total value of $\$ 283$ million for market value only.

Only one Pareto-optimal solution achieves a food target equal to 53 percent of baseline corn production (see Table 8, last row). That configuration produces 0.65 million tons of corn, reduces the nitrogen load by 28 percent and the sediment load by 41 percent, and generates the equivalent of 32.8 million gallons of fuel with about one-third of that fuel obtained from the bioenergy crops. Interestingly, about 8.5 percent of the watershed is dedicated to energy crops (4.05 percent to miscanthus and 4.00 percent to switchgrass), which is roughly equal to the total area of marginal land. In Figure 6, we present the distributions of energy crop production and marginal land under that solution. Although the energy crops sometimes are produced on marginal land, they are concentrated in several sub-basins and mostly in the central part of the watershed. Only 18.6 percent of the marginal land in the watershed is used for energy crops in this solution.

\section{Conclusions and Caveats}

We evaluate the empirical tradeoffs between food, fuel, and water quality by applying a simulation-optimization framework to an important watershed in the U.S. Corn Belt. Furthermore, we explore whether planting bioenergy crops on marginal land is optimal. We identify the highest valued land allocations by evaluating the output of food and fuel for four sets of market prices and potential nonmarket water quality benefits (reductions in nitrogen and sediment loads). Our empirical findings suggest that the optimal use of land within a watershed when food, fuel, and water quality are valued differs substantially from when only food and fuel are valued. The results also imply, not surprisingly, that the optimal land use depends on the prices and values of the outputs. Finally, use of an arbitrary rule of growing bioenergy crops on marginal land can result in substantial losses of social welfare. However, using the current framework, we cannot determine the societal distribution of these losses.

Additionally, we provide an extensive sensitivity analysis to account for the fact that the production costs are likely to differ across types of fuel by considering smaller fuel prices for biofuels. We further consider other potential environmental benefits (such as wildlife habitat and biodiversity) associated with production of bioenergy crops by placing a significantly 
higher value on the nonmarket water quality benefits. Finally, we incorporate soil carbon-sequestration benefits to consider the sensitivity of the findings.

Several caveats are important to note. Our extended sensitivity analysis covers some aspects such as different production costs for ethanol and biofuel and inclusion of additional environmental benefits. However, it is made ex post of optimization. In addition, the soil carbon-sequestration values were obtained from different sources and may not best reflect carbon sequestration in the study area. A more complete analysis would require inclusion of all of those factors in the optimization framework. In spite of these caveats, our findings suggest that strict adherence to placing bioenergy crops on marginal land is unlikely to be socially optimal.

\section{References}

Anderson, K., and S. Nelgen. 2012. "Agricultural Trade Distortions during the Global Financial Crisis." Oxford Review of Economic Policy 28(2): 235-260.

Arnold, J.G., R. Srinivasan, R.S. Muttiah, and J.R. Williams. 1998. "Large Area Hydrologic Modeling and Assessment Part I: Model Development." Journal of the American Water Resources Association 34(1): 73-89.

Arnold, J.G., and N. Fohrer. 2005. "SWAT 2000: Current Capabilities and Research Opportunities in Applied Watershed Modelling." Hydrological Processes 19(3): 563-572.

Deb, K. 2001. Multi-Objective Optimization Using Evolutionary Algorithms (Volume 16). Hoboken, NJ: John Wiley \& Sons.

Gassman, P.W. 2008. "A Simulation Assessment of the Boone River Watershed: Baseline Calibration/Validation Results and Issues and Future Research Needs." Ph.D. dissertation, Iowa State University, Ames, Iowa. Available at http://lib.driastate.edu/ rtd/15629.

Gassman, P.W., M.R. Reyes, C.H. Green, and J.G. Arnold. 2007. "The Soil and Water Assessment Tool: Historical Development, Applications, and Future Research Directions." Transactions of the ASABE 50(4): 1211-1250.

Gassman, P.W., A.M. Sadeghi, and R. Srinivasan. 2014. "Applications of the SWAT Model Special Section: Overview and Insights." Journal of Environmental Quality 43(1): 1-8.

Gelfand, I., R. Sahajpal, X.S. Zhang, R.C. Izaurralde, K.L. Gross, and G.P. Robertson. 2013. "Sustainable Bioenergy Production from Marginal Lands in the U.S. Midwest." Nature 493(7433): 514-517.

Godfray, H.C.J., J.R. Beddington, I.R. Crute, L. Haddad, D. Lawrence, J.F. Muir, J. Pretty, S. Robinson, S.M. Thomas, and C. Toulmin. 2010. "Food Security: The Challenge of Feeding Nine Billion People." Science 327(5967): 812-818.

Gramig, B.M., C.J. Reeling, R. Cibin, and I. Chaubey. 2013. "Environmental and Economic Tradeoffs in a Watershed When Using Corn Stover for Bioenergy." Environmental Science and Technology 47(4): 1784-1791.

Guariso, A., M.P. Squicciarini, and J. Swinnen. 2014. "Food Price Shocks and the Political Economy of Global Agricultural and Development Policy." Applied Economic Perspectives and Policy 36(3): 387-415.

Follett, R.F., K.P. Vogel, G.E. Varvel, R.B. Mitchell, and J. Kimble. 2012. "Soil Carbon Sequestration by Switchgrass and No-till Maize Grown for Bioenergy." BioEnergy Research 5(4): 866-875.

Harvey, M., and S. Pilgrim. 2011. "The New Competition for Land: Food, Energy, and Climate Change." Food Policy 36: S40-S51. 
Hausman, C., M. Auffhammer, and P. Berck. 2012. "Farm Acreage Shocks and Crop Prices: A Svar Approach to Understanding the Impacts of Biofuels." Environmental and Resource Economics 53(1): 117-136.

Khanna, M., B. Dhungana, and J. Clifton-Brown. 2008. "Costs of Producing Miscanthus and Switchgrass for Bioenergy in Illinois." Biomass and Bioenergy 32(6): 482-493.

Kling, C.L. 2011. "Economic Incentives to Improve Water Quality in Agricultural Landscapes: Some New Variations on Old Ideas." American Journal of Agricultural Economics 93(2): 297-309.

Krysanova, V., and M. White. 2015. "Advances in Water Resources Assessment with SWATan Overview." Hydrological Sciences Journal 60(5): 771-783.

Lewis, S.M., and M. Kelly. 2014. "Mapping the Potential for Biofuel Production on Marginal Lands: Differences in Definitions, Data, and Models across Scales." ISPRS International Journal of Geo-information 3(2): 430-459.

Limayem, A., and S.C. Ricke. 2012. "Lignocellulosic Biomass for Bioethanol Production: Current Perspectives, Potential Issues, and Future Prospects." Progress in Energy and Combustion Science 38(4): 449-467.

Morales, M., J. Quintero, R. Conejeros, and G. Aroca. 2015. "Life Cycle Assessment of Lignocellulosic Bioethanol: Environmental Impacts and Energy Balance." Renewable and Sustainable Energy Reviews 42(_): 1349-1361.

Natural Resources Conservation Service. 2009. Interim Final Benefit-Cost Analysis for the Environmental Quality Incentives Program. NRCS, Washington, DC. Available at www. nrcs.usda.gov/Internet/FSE_DOCUMENTS/nrcs143_007977.pdf.

— . 2013. "Summary Report: 2010 National Resources Inventory." NRCS, U.S. Department of Agriculture, Washington, DC. Available at www.nrcs.usda.gov/Internet/FSE_ DOCUMENTS/nrcs142p2_006983.pdf (accessed May 31, 2016).

_ 2015. "Web Soil Survey" web page / database. NRCS, USDA, Washington, DC. Available at http://websoilsurvey.nrcs.usda.gov.

Nature Conservancy. 2012. "Great Rivers Partnership: Boone River." The Nature Conservancy, Arlington, VA. Available at www.greatriverspartnership.org/en-us/NorthAmerica/ Mississippi/Pages/Boone-River.aspx.

Nicklow, J., P. Reed, D. Savic, T. Dessalegne, L. Harrell, A. Chan-Hilton, M. Karamouz, B. Minsker, A. Ostfeld, A. Singh, E. Zechman, and ASCE Task Committee on Evolutionary Computation in Environmental and Water Resources Engineering and et al. 2010. "State of the Art for Genetic Algorithms and Beyond in Water Resources Planning and Management." Journal of Water Resources Planning and Management 136(4): 412-432.

Peterson, G.M., and J.K. Galbraith. 1932. "The Concept of Marginal Land." Journal of Farm Economics 14(2): 295-310.

Rabotyagov, S., T. Campbell, M. Jha, P.W. Gassman, J. Arnold, L. Kurkalova, S. Secchi, H. Feng, and C.L. Kling. 2010. "Least-cost Control of Agricultural Nutrient Contributions to the Gulf of Mexico Hypoxic Zone.” Ecological Applications 20(6): 1542-1555.

Rabotyagov, S., A. Valcu-Lisman, and C. Kling. 2016. "Resilient Provision of Ecosystem Services from Agricultural Landscapes: Tradeoffs Involving Means and Variances of Water Quality Improvements." American Journal of Agricultural Economics (forthcoming).

Ray, D.K., N.D. Mueller, P.C. West, and J.A. Foley. 2013. "Yield Trends Are Insufficient to Double Global Crop Production by 2050." Plos One 8(6).

Ribaudo, M., J. Savage, and M. Aillery. 2014. "An Economic Assessment of Policy Options to Reduce Agricultural Pollutants in the Chesapeake Bay." Research Report 166, Economic Research Service, Washington, DC.

Shortall, O.K. 2013. "Marginal Land for Energy Crops: Exploring Definitions and Embedded Assumptions." Energy Policy 62: 19-27.

Tadesse, G., B. Algieri, M. Kalkuhl, and J. von Braun. 2014. "Drivers and Triggers of International Food Price Spikes and Volatility." Food Policy 47(Aug): 117-128. 
Tokgoz, S., A. Elobeid, J. Fabiosa, D.J. Hayes, B.A. Babcock, T.H. Yu, F.X. Dong, and C.E. Hart. 2008. "Bottlenecks, Drought, and Oil Price Spikes: Impact on U.S. Ethanol and Agricultural Sectors." Review of Agricultural Economics 30(4): 604-622.

Valcu, A.M. 2013. "Agricultural Nonpoint Source Pollution and Water Quality Trading: Empirical Analysis under Imperfect Cost Information and Measurement Error." Ph.D. dissertation, Department of Economics, Iowa State University.

Valcu-Lisman, A.M., P.W. Gassman, C. Kling, and R. Arritt. 2016. "Cost-effectiveness of Reverse Auctions for Watershed Nutrient Reductions in the Presence of Climate Variability: Final Report to the Iowa Water Center." Center for Agricultural and Rural Development, Iowa State University, Ames.

Werling, B.P., T.L. Dickson, R. Isaacs, H. Gaines, C. Gratton, K.L. Gross, H. Liere, C.M. Malmstrom, T.D. Meehan, L. Ruan, and B.A. Robertson. 2014. "Perennial Grasslands Enhance Biodiversity and Multiple Ecosystem Services in Bioenergy Landscapes." Proceedings of the National Academy of Sciences 111(4): 1652-1657.

Wright, B.D. 2011. "The Economics of Grain Price Volatility." Applied Economic Perspectives and Policy 33(1): 32-58.

Zitzler, E., M. Laumanns, and L. Thiele. 2002. "SPEA2: Improving the Strength Pareto Evolutionary Algorithm for Multiobjective Optimization." K.C. Giannakoglou, ed., Evolutionary Methods for Design, Optimization, and Control with Applications to Industrial Problems. Athens, Greece: International Center for Numerical Methods in Engineering. 